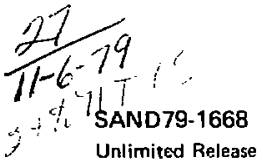

\title{
MASTER
}

\section{An Overview of the Software for the Telemation/Sandia Unattended Video Surveillance System}

Paul D. Merillat

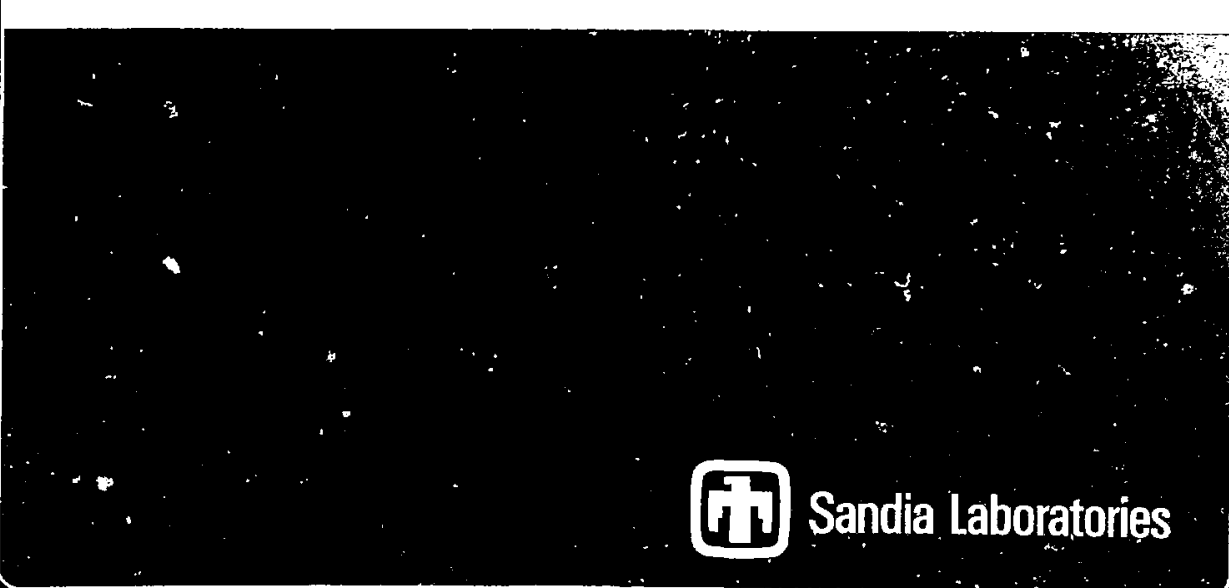


SAND T9-16Ga

Unlinjled Rejease

printed Cotober 1979

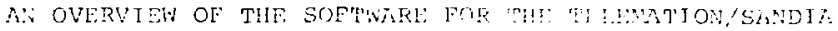

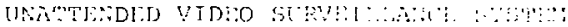

Pül D. Horillat

r.roject linginon:ing D: isio:; 1759

Sancia Laboratorius

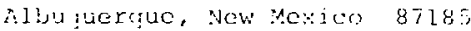

\section{ABSTRACT}

A microprocessor has been used to provide the major control functions in the Telemation/Sandia unattended video survellance system. The software in the microprocessor provides control of the various hardwaro components and provides the capability of

interactive communications with lie operator. This document, in corjunction with the comimented source listing, defines the philosophy and function of the software. It is assumed that the reader is lamiliar with the RCA 1802 COS: MC miccoprocessor anci has a reasonable computer science background.

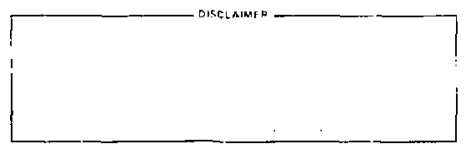




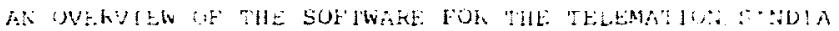

UNATTENDED VIDEO SUKVEITLANEE SYSTEA

SYSTIM ONtLivitr

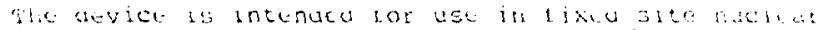

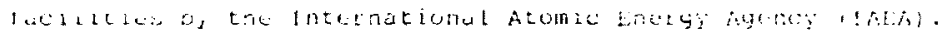

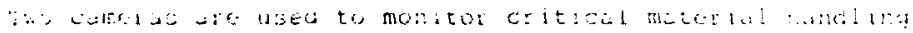

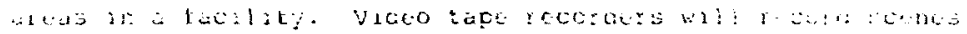

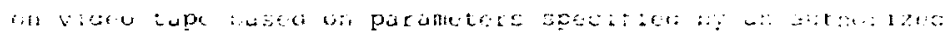

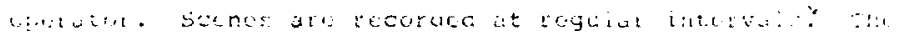
.

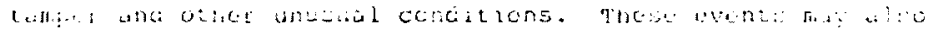

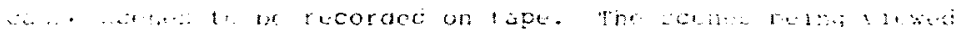

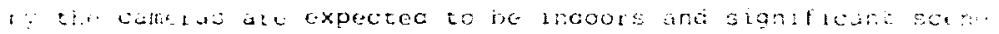

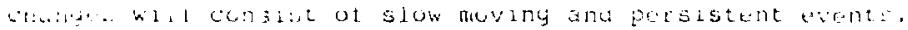

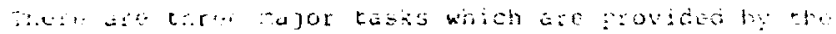

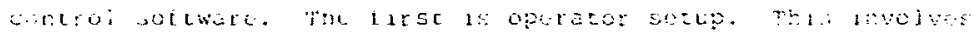

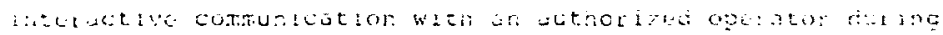

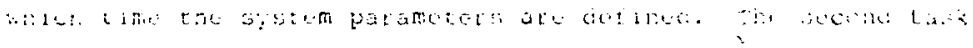


is normal operation. This involves the observation of tre. scene. The system, while in this mode, is constanty checking lor slgnit leant scene changes. Scencs are recorded at regular

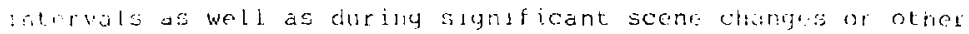

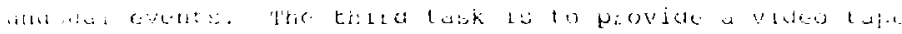

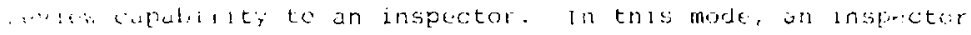
‥ ra A: : thitlous act has occlirer.

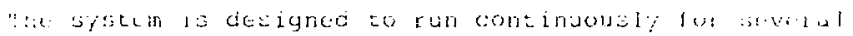

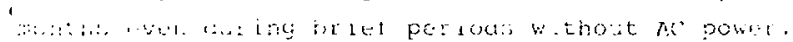

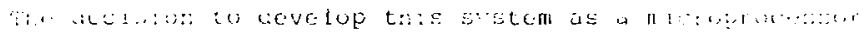

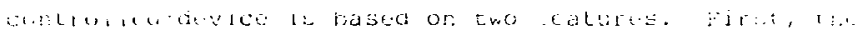

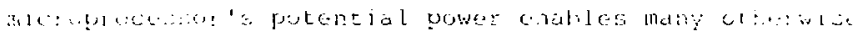

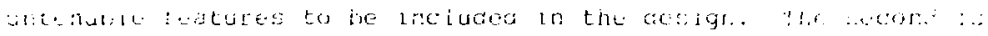

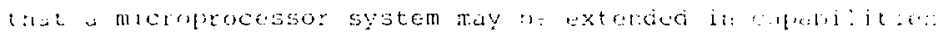

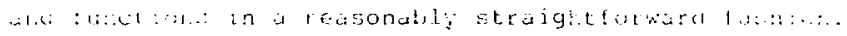

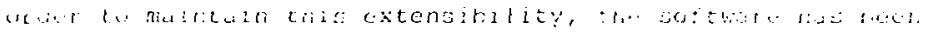

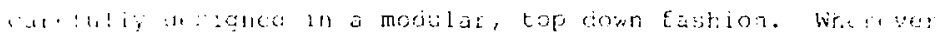

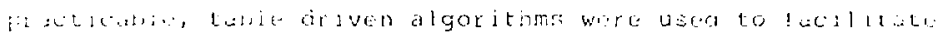

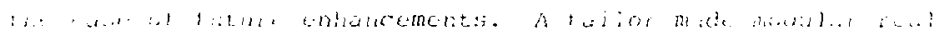

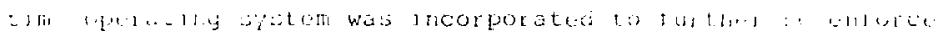
L1.1.: $; 1,2$.

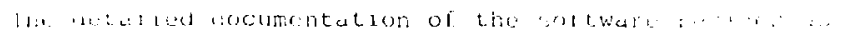

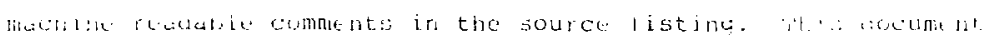

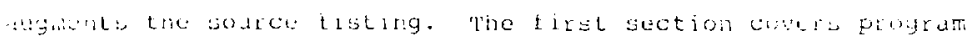

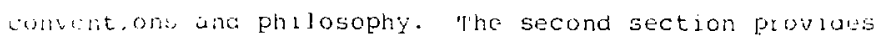
delults ot line workings of the more complex aspects ol the

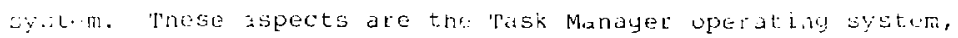

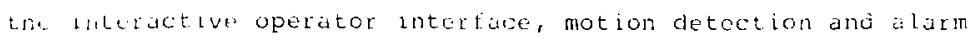
s: ni: : coscaling methods: 
The buik of the programing conventions were developed in an attempt to compensate for the design restrictions imposed by the RLA 1802 cosmaC microprocossor. The 1802 was originally sejects because of its low power reguilements. The 2802 was the only well supported cmos microprocessor available at the time oi hardware commitment, however, the 1802 has several severe arawbacks to its architecture.

l'te generai approact. for this compeneation was :o reveisp un extensive hacro lirrary thich contains a the range of peruo irstructions to augnant the 1 inited and awsict

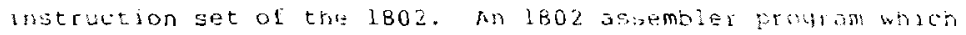
uses ont $y$ the busic 1802 instruction set ja noticeably dithicult to follow because of the little mork cacn andividual iroz inst uction performs. Fot cxample, slppose me wisnes to 1000 one uf the genetai purpose registers with a two byte vatidble. lo luad the two byte vatiable, XYZ, into logister k9 weili reguire the toilowiag $: 802$ coms:

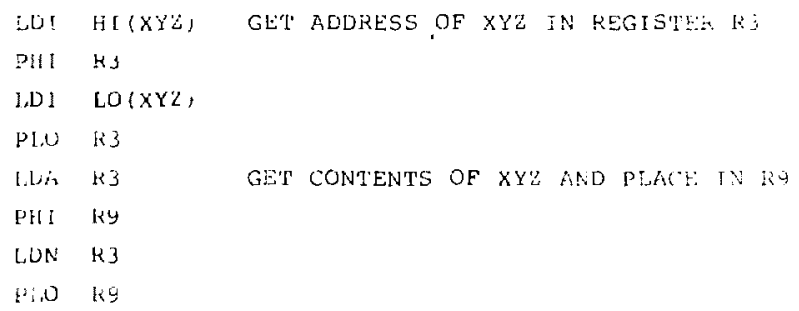


that the proyrammer is required to specifically test the eight instruction sequences each time he ises it. The second is that the soutce code oecomes unwieldy ir that only a few simple data riatifulazions are written per pacte of code chus masking thn

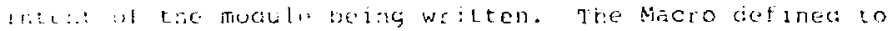

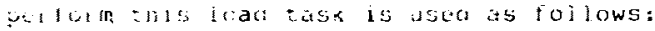

1. K9, XY' GET THE CONTENTS OF XYZ IN REGIS'l'ER R9

T: Ficro processor wi l qurerite the eidht listructions

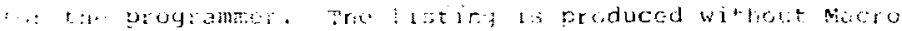

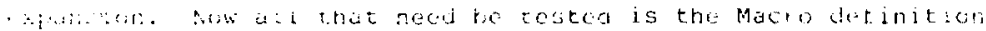

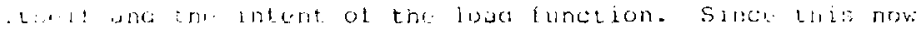

: At

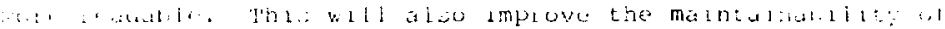

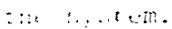

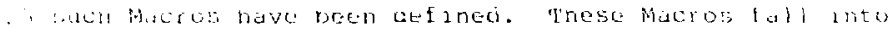

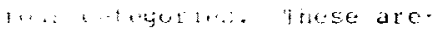

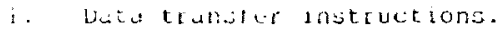

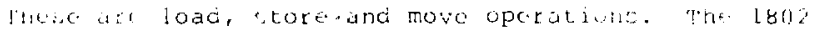

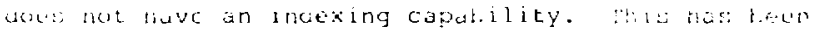

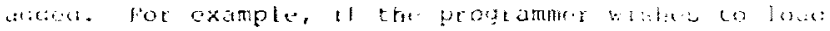

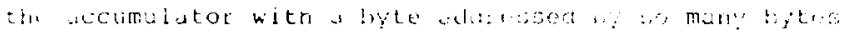

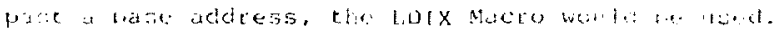

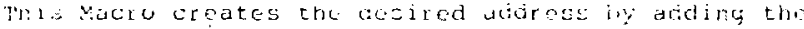

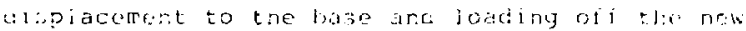
entiveses.

$\therefore$ bojak mantplation arstidetions.

Pise 1802 does rot nave a tris stack nor does it hire Etack ranoling instructions. These have l,eer. ociec

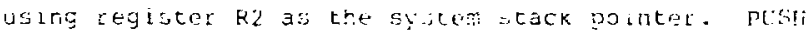
dilo POP Hacros provide bilis service. 
3. Compare and duta modification lrstructions.

The lBo2 has no compare instructions. Compares are cone ising subtract with a subsequent check for a tor row condition. The Cl Macro aios in cetrecting

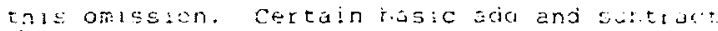
tunctons are also implemented using Macras.

4. Subroutine transfer instructions.

One of the most awkward fratures of the isot is it: nanding of storoutanes. The design ol tre: ma:

wictates that hagt speed wardutine lantige : :

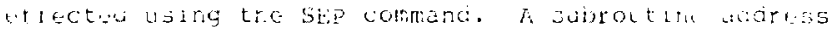

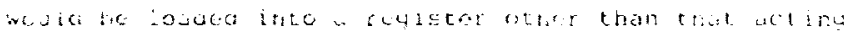

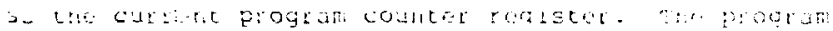

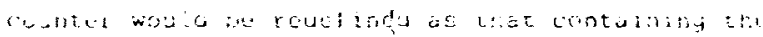

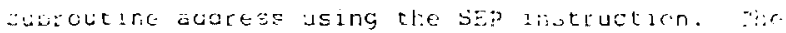

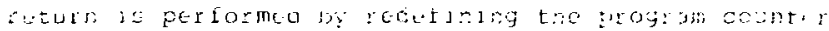

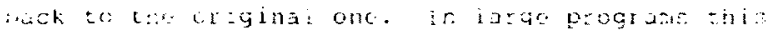

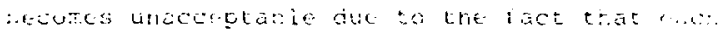

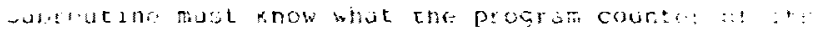

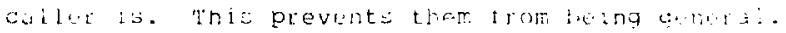

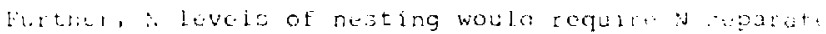
worat wh counter regasere.

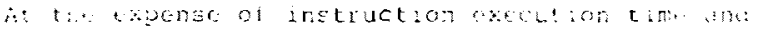

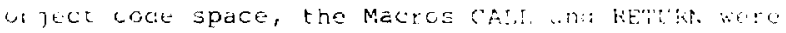

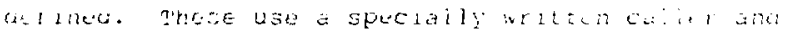

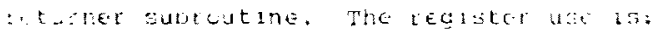

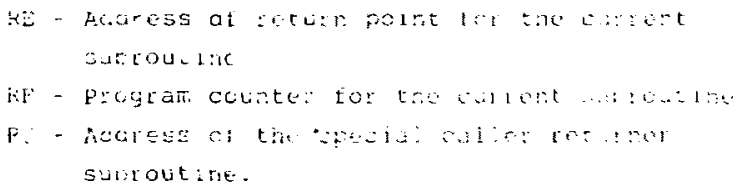


Suhroutine calls are effected by:

i. Pushing the current return point (RE) onto the system stäk.

2. Luading RE, with tro adaress of the subrcutine to be called.

3. Setting the program counter to kC loaling the spacial caller/returner surroutinel.

4. This special routine interchanges the contents ol Kri with RF and tiet s the frogrim countor to KF.

He Lurns aro ettected by:

1. Setting the poograll counter to ki.

2. The spocial subroutine again interchanges the contents of RE with RF and ets the program counter buck to RF hence returning control to the calling program.

3. The: cilling program pops its return point bick into Re from the system stack.

The instivition yata length ior this $1 \mathrm{~s} 55$ in eruetions. This, nowever, provides true subroutute cupublictes whict lis imperative trom elsi: stanapoint of development and maintainability.

- lit uraer lor the Macros to work most oi them require a lite work liglster. This has peen designated as $k 3$ in this system und ts not available for use by the programmer other than as wutumaticali; generated trom the Mac:os.

The 1802 has a series of instructions known as short branch inotructions. These branches, when they occur, only modify thr: 
Low order elght bits of the plogram counter registe: and hence their setuviour at dependent on memory page boundaries. This means that any module using these instructions is not

reibctable. For tris teason shot branct instructions are not

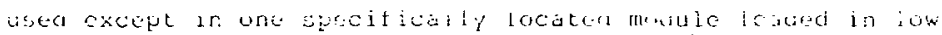

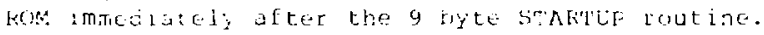

The irput/output arcintecture of the 1802 is the iast major

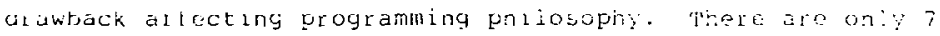

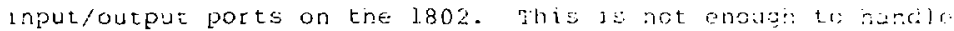

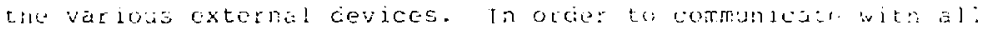
tir: cevecs, it was necessar to multajer the ports. Inis

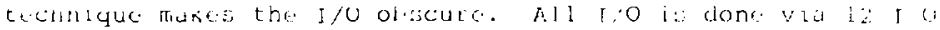

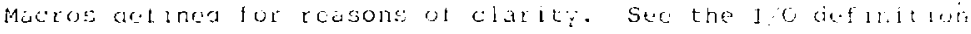

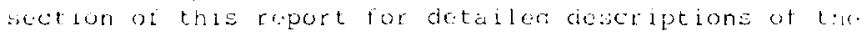
intertuces with the external devicus.

\section{PKOGKAMMING CONVENTIONS}

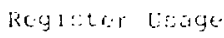

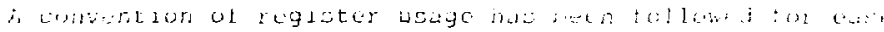

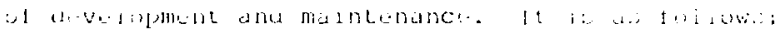

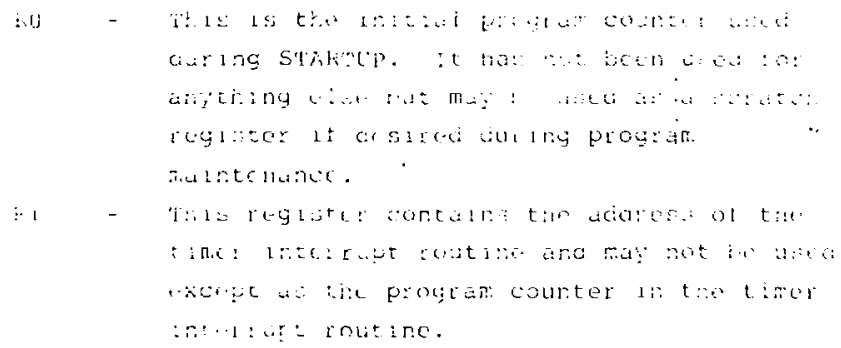


This is the adciress of the next frec eloment in thr: system stack.

R3 - Phis is the Macro scratch ieglster and may nut be wised by the programmer sxcept as it le automaticaliy usicd by Macros.

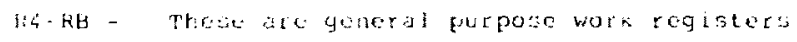
usci ry the Wormi t Tarks. The cortents of trese ragisters are juved by the lask Hinager when a lask relinqulshes control.

RC - Thes registor contains the ucirese ol the

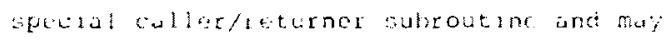
not bo usea except as the program counter for that susicoutine.

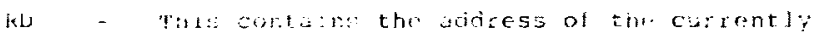

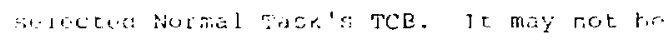
urec lor an; othre purpose. 15ec rase Manseger description.

le - Jnie regietor contuane the roturn point of cul curbent routine. It may not be modifires

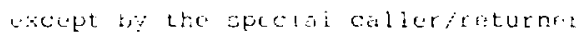

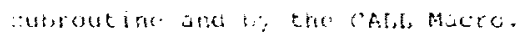

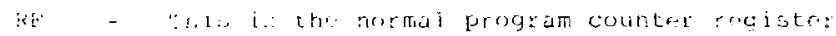

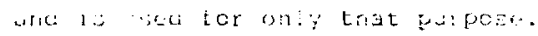

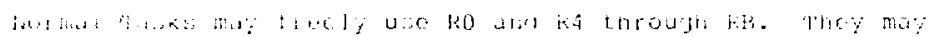

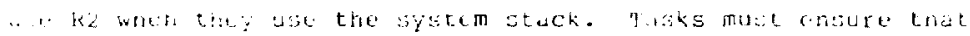

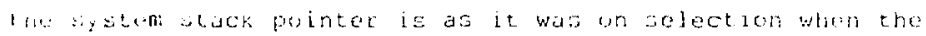

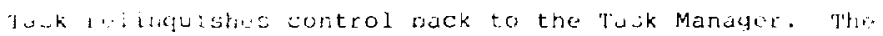

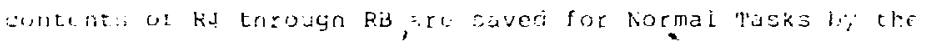
idik Mundyut.
}

Kuplu POlling Jäks may ust RO, Ra through FB and Fu hut unlitic. Normal Tasks, k4 lingough RB are nret saved for it. R2 ind $y$ be ustet when lia stack is raquired. 


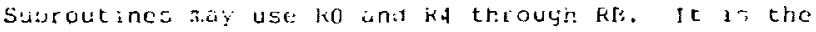
respon:si,l lity of the suirouliros to acstora tine os lginal contents of $k 4$ through kB on return to the calling routine. k?

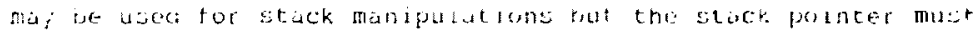

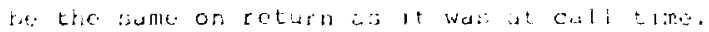

The $x$ roghster pointe: may be cratigen as noeded. Frograme

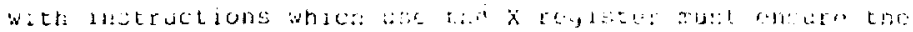

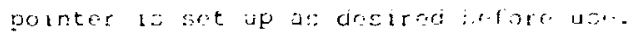

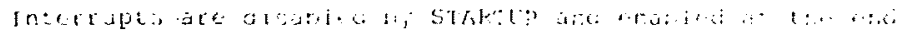

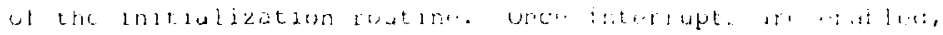

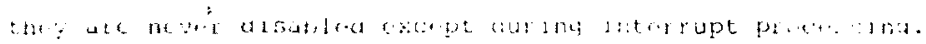

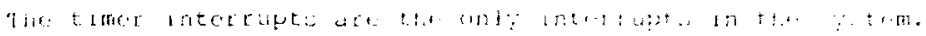

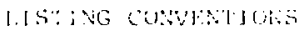

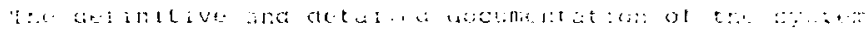

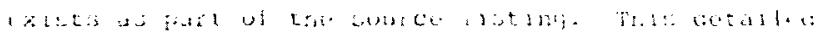

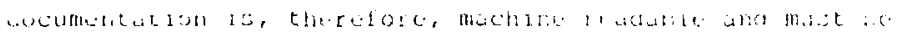

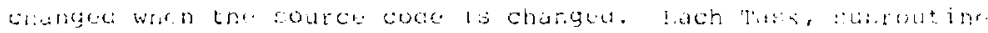

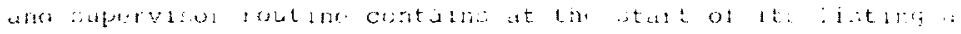

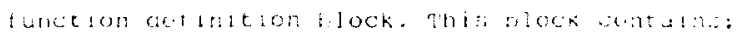

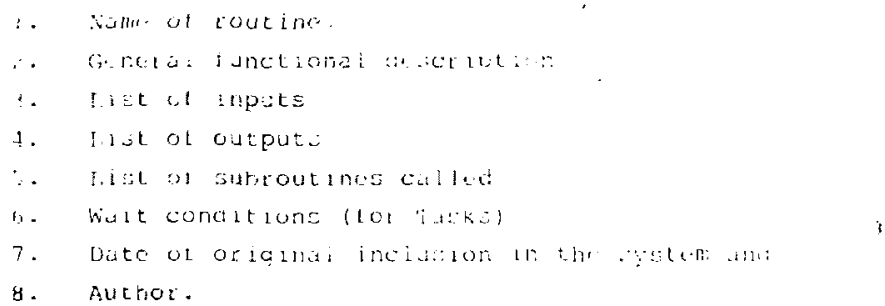




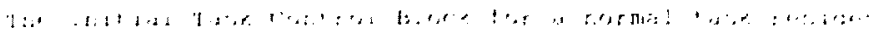

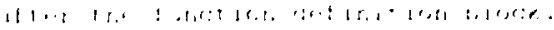

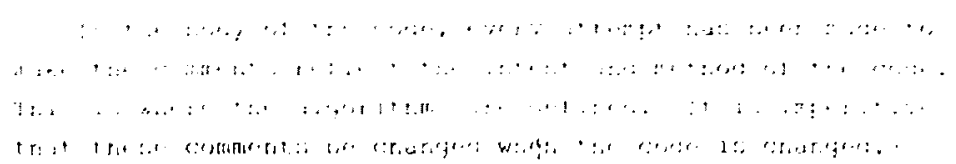




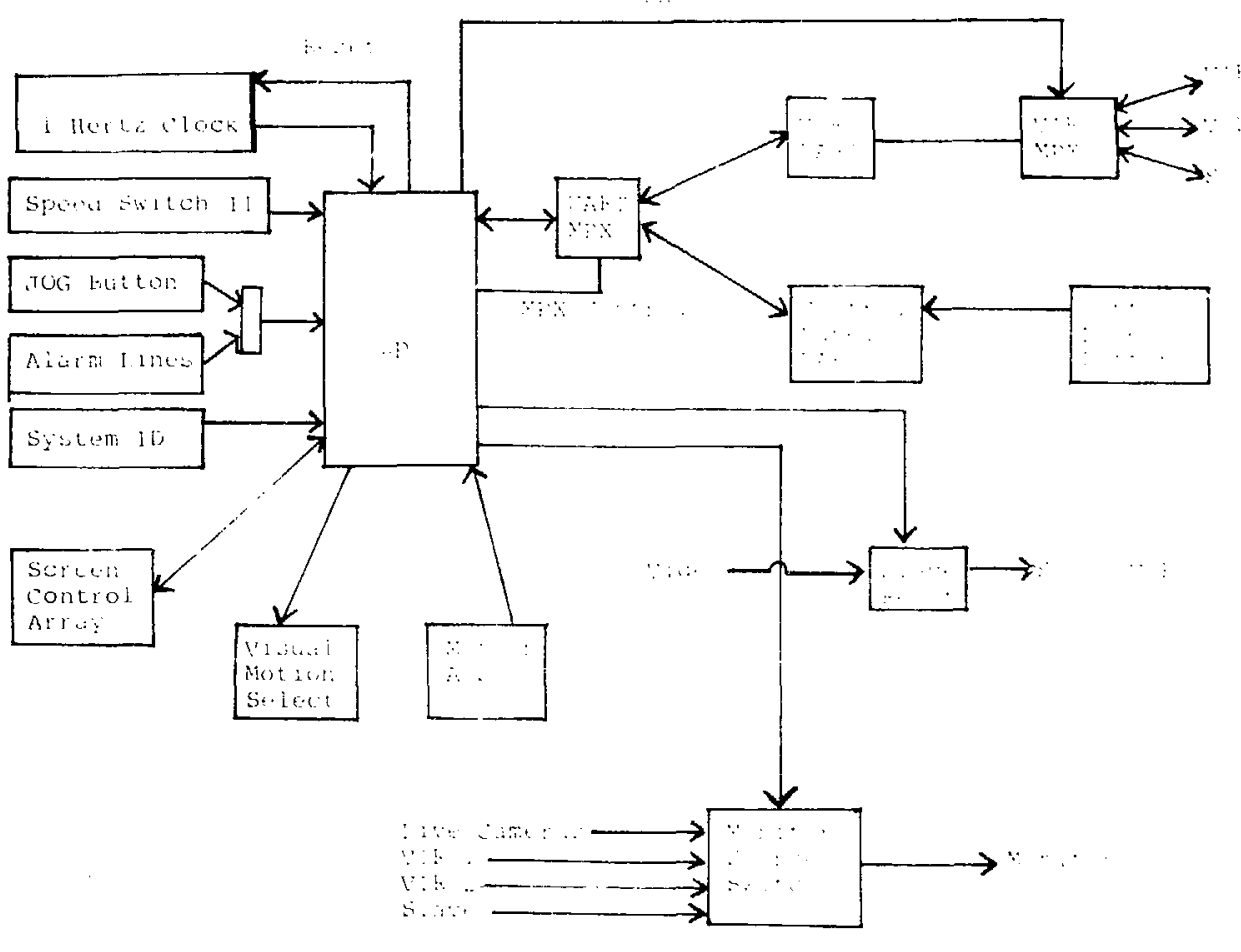




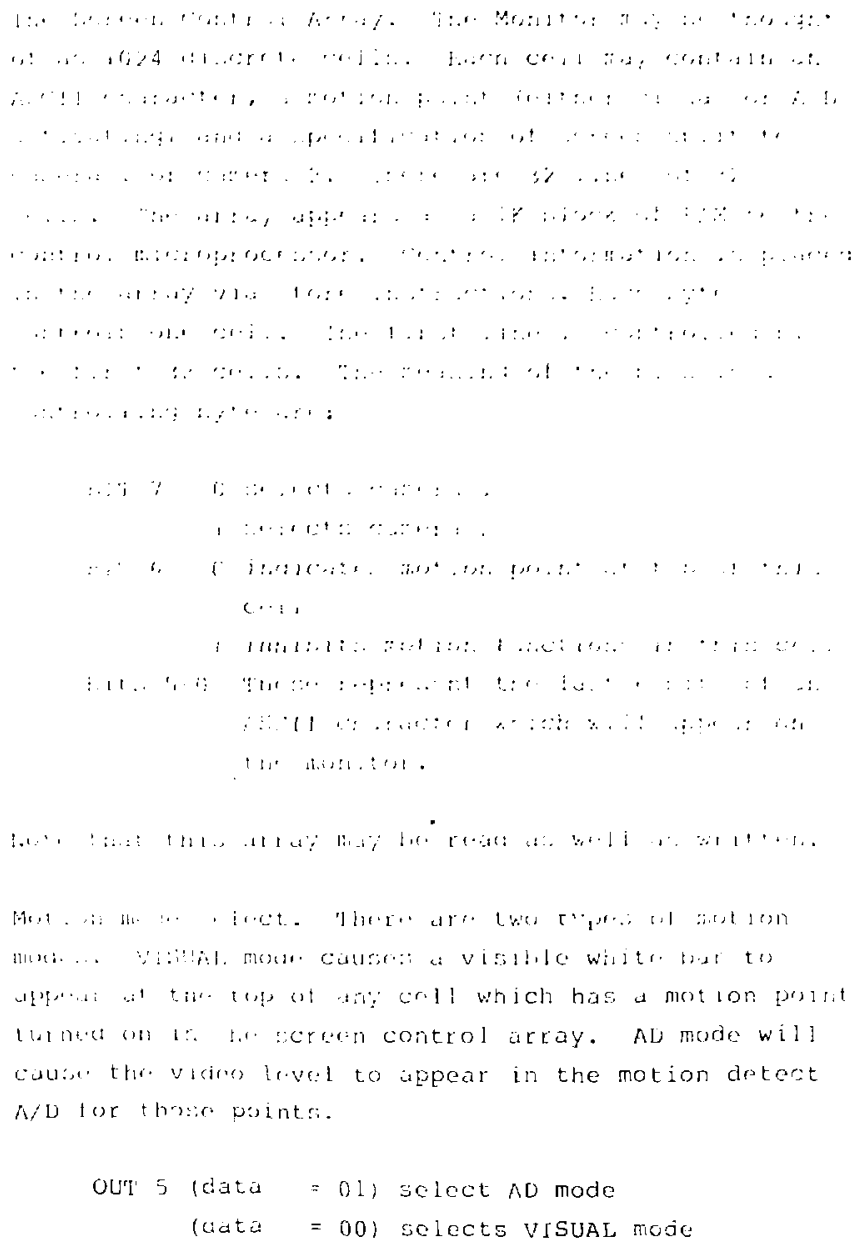




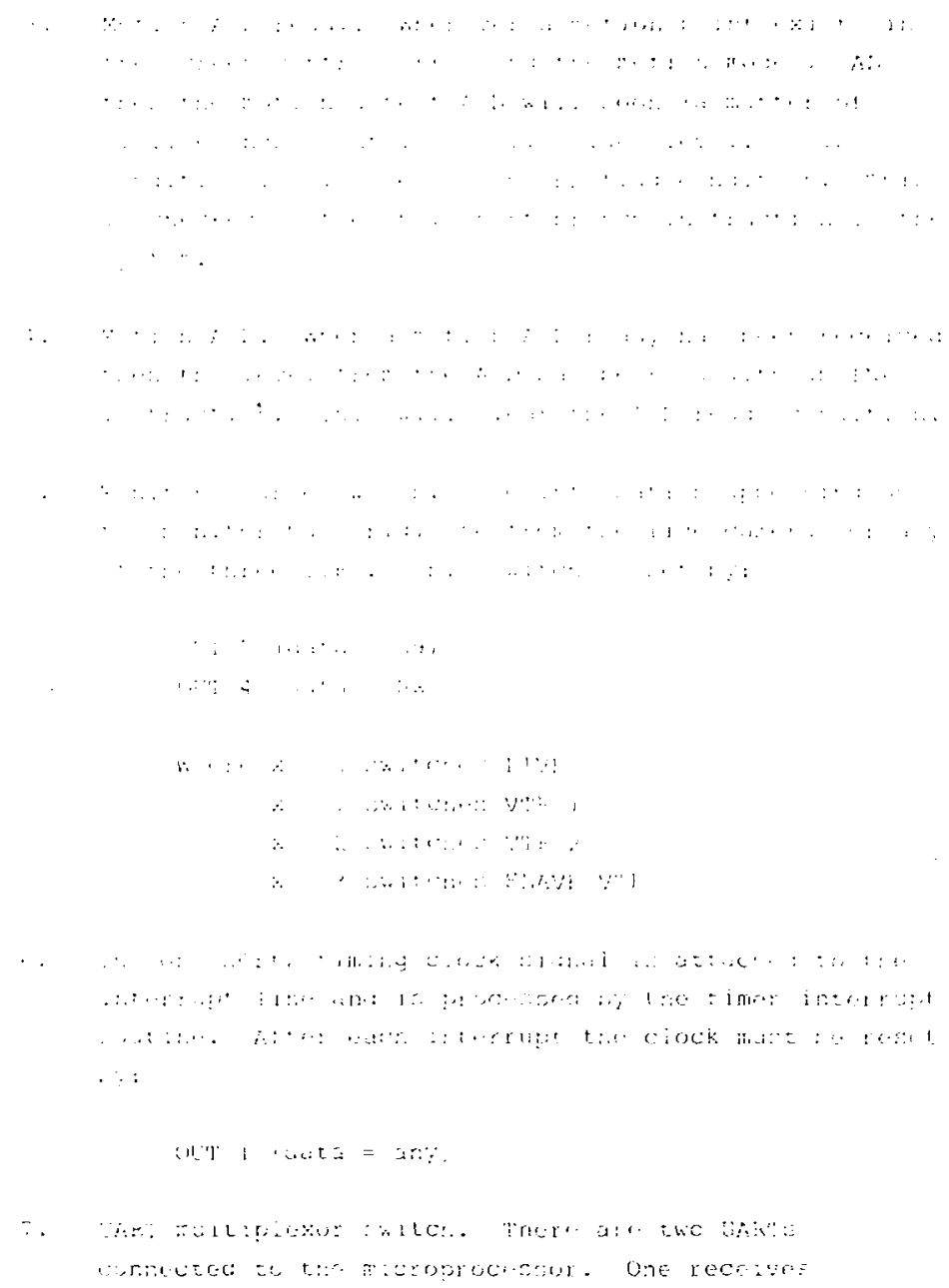

: 


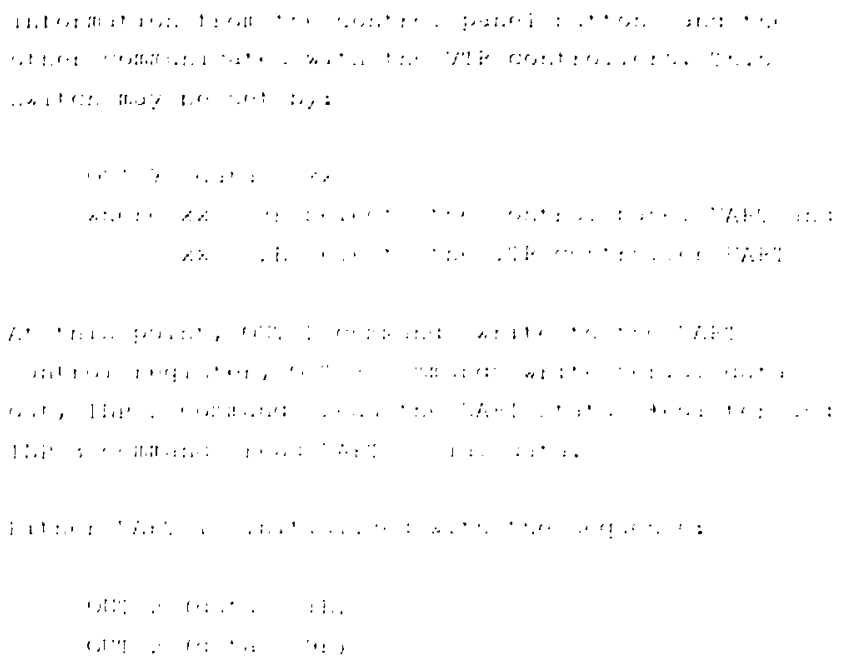

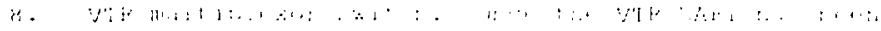

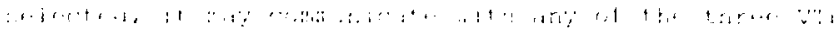

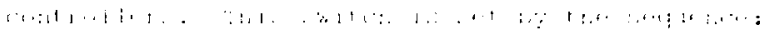

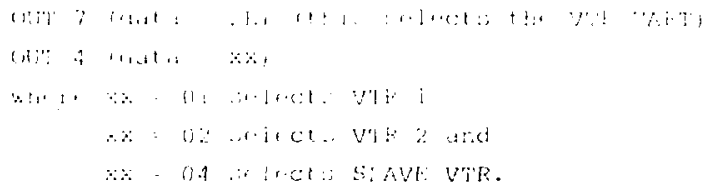




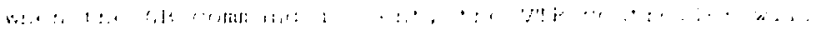

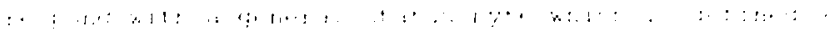

$$
\begin{aligned}
& : \quad: 1, \quad:
\end{aligned}
$$

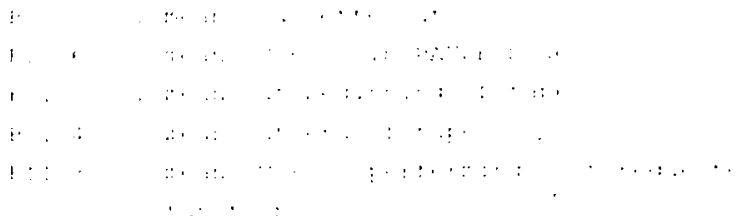

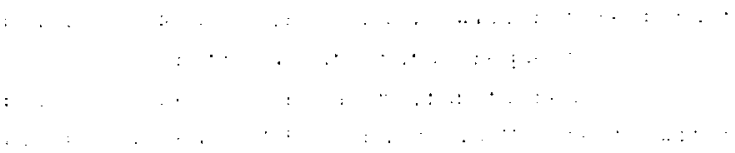

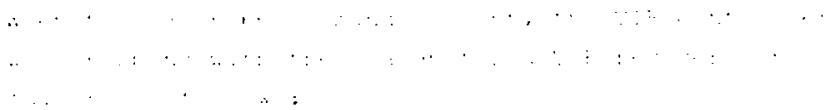

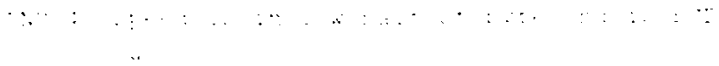

- 


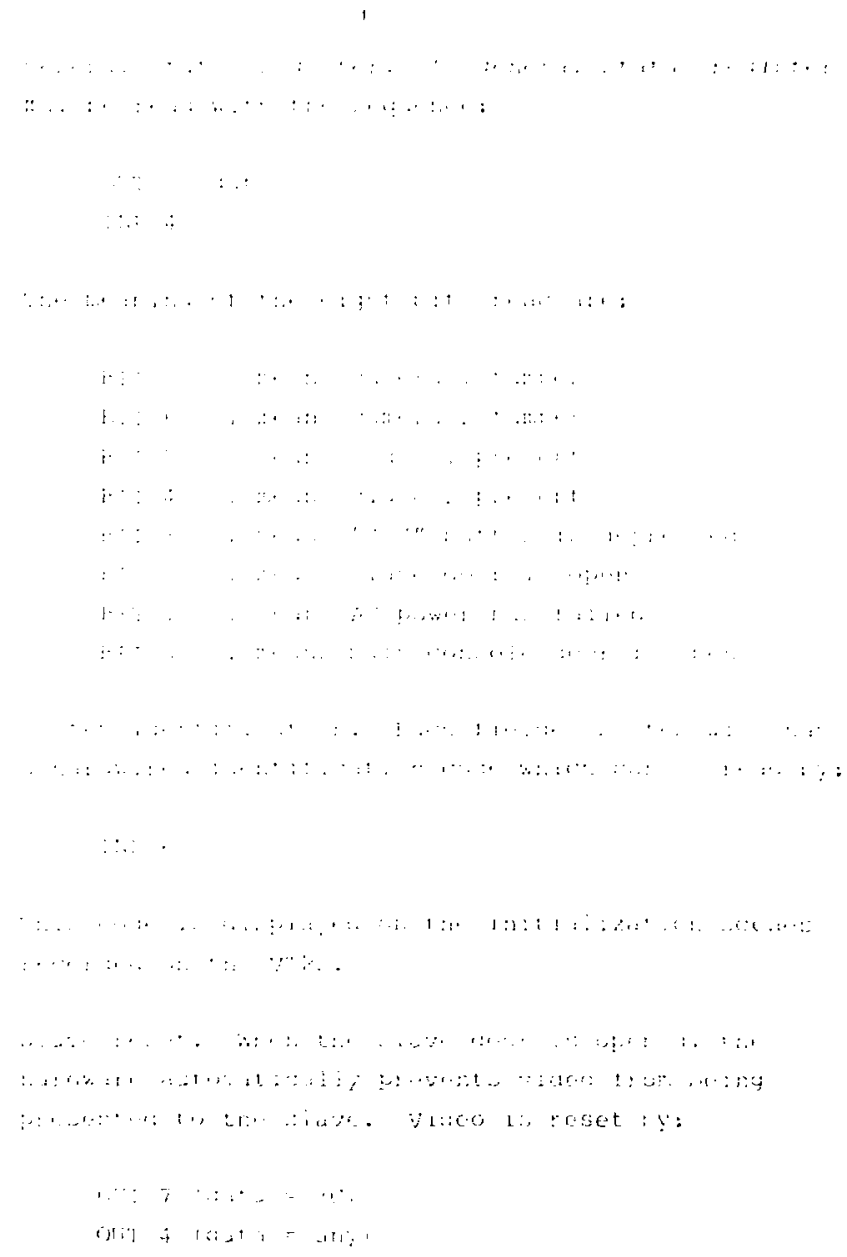




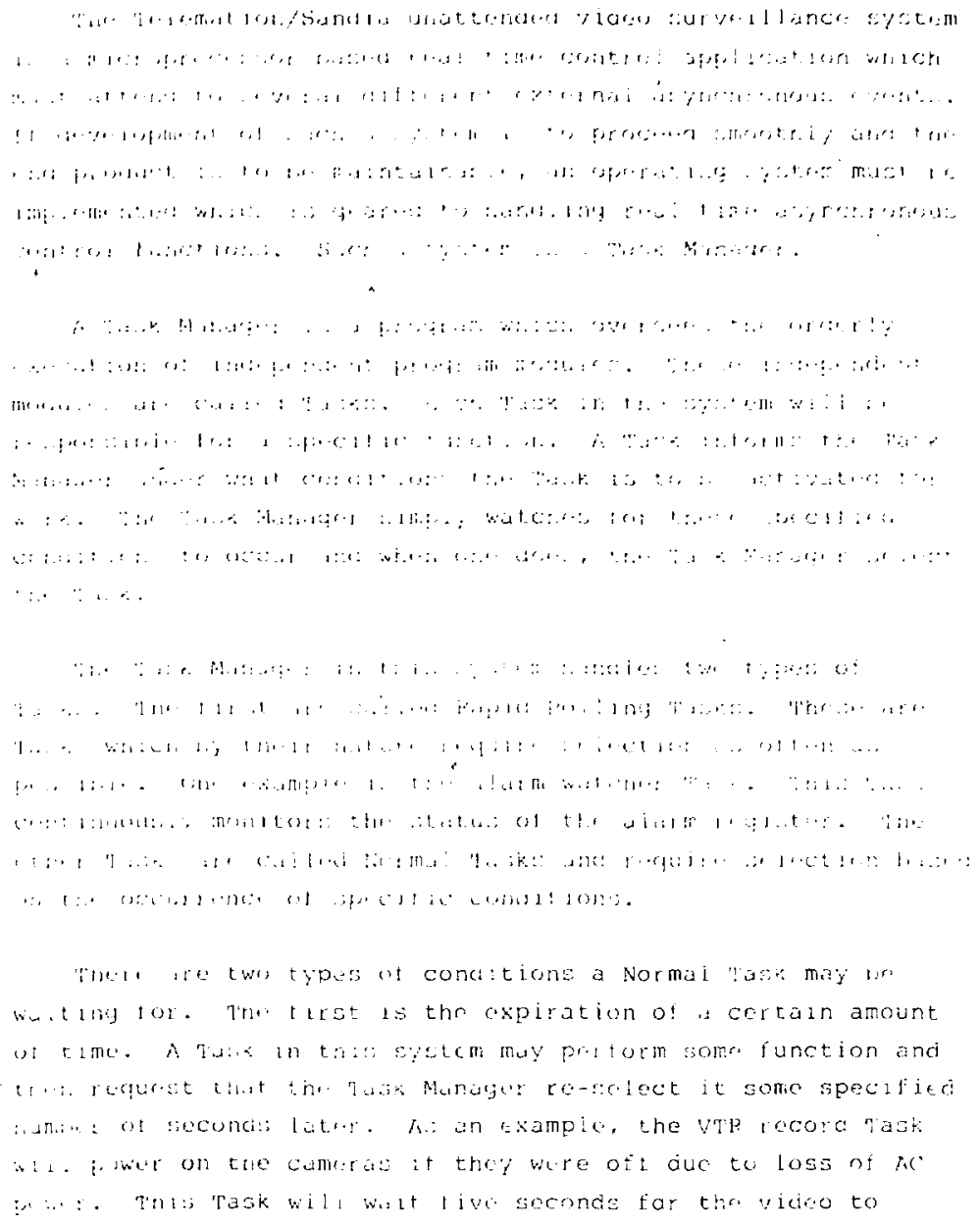




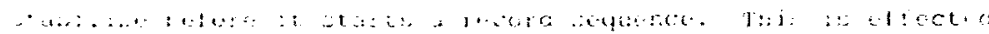

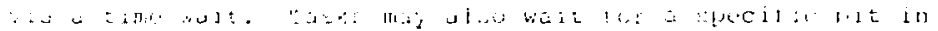

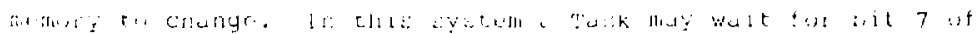

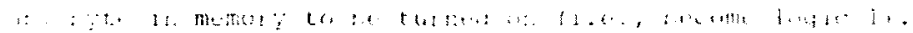

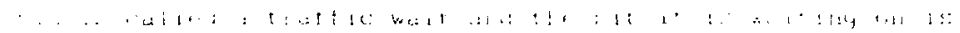

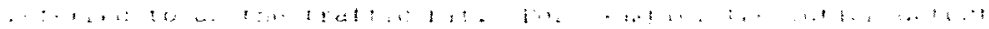

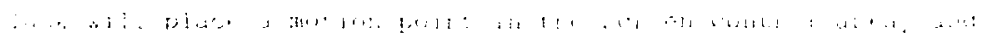

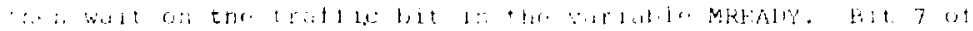

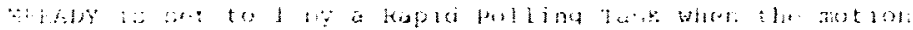

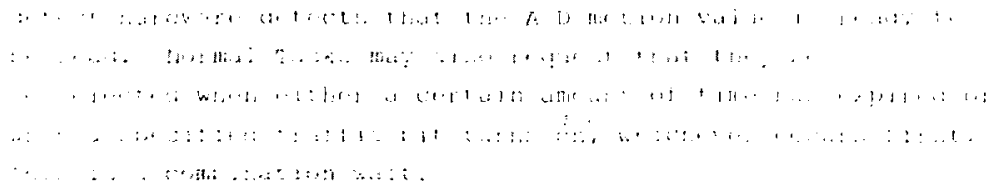




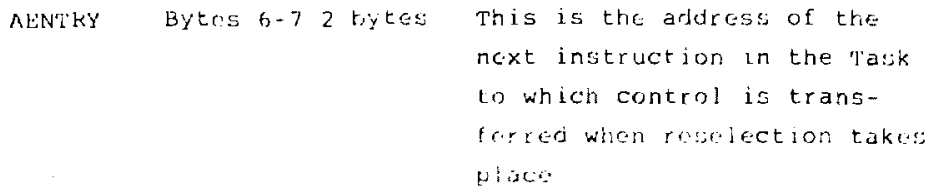

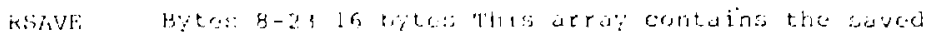
contrintes of regleters R4 cheough RB when the Task r. 1 inrulair a rontrol.

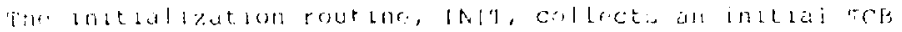

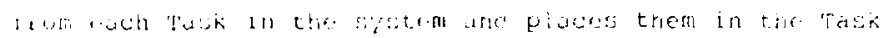

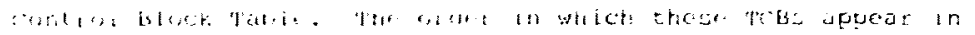

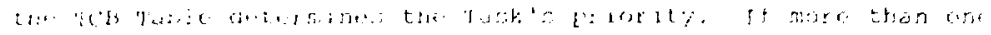

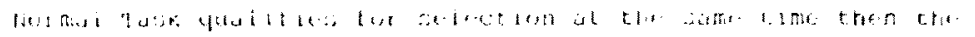

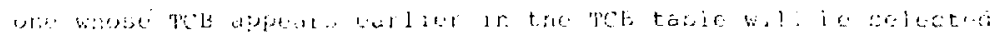
$: 1: \ldots i$.

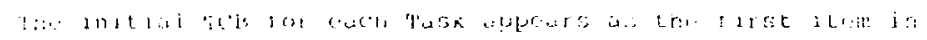

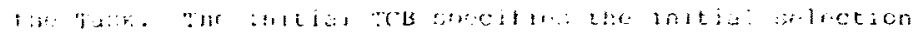

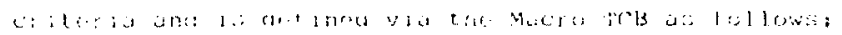

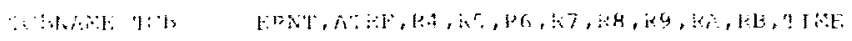

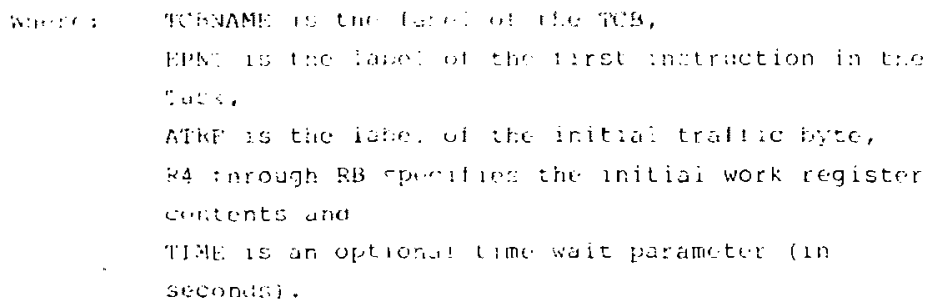




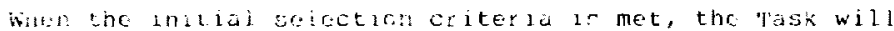
ve istected tor the first time. Subseguent selection will be bused on new selection ctiteria set up by the Task when it rimauntios cuntrol.

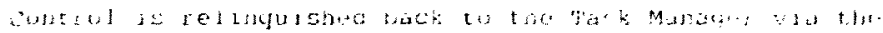
Musty Whit at follows:

\section{WAT T' TPAF, ATRF O: \\ WIII TIMLER $\mathrm{RK}$ OH \\ WI:T T: COMB, $A$ Th, KN}

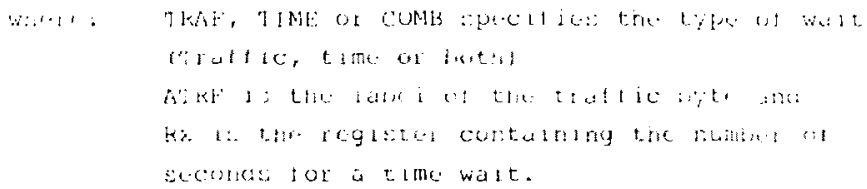

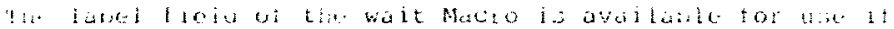
a.: $: 1 \mathrm{r} \cdot \mathrm{d}$.

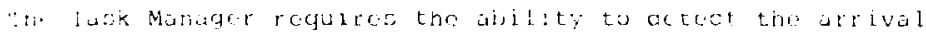

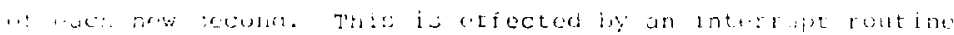

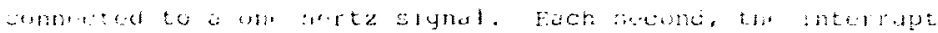

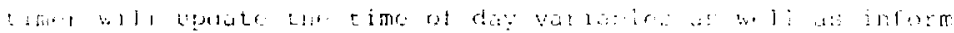

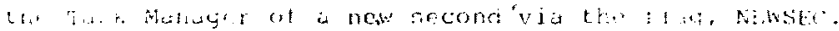

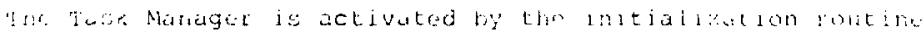

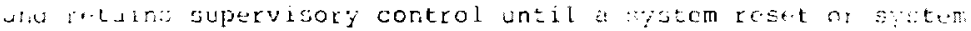

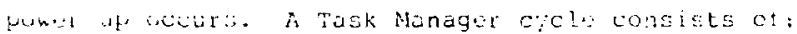

1. Lal al kupia polling Tasks.

2. It NEhSEC is non-zero, thon dectement rach t lmb wat + Lelu ror cyery task doing a the wait and tath aro NFWSEc. Don't decrement pist cero. 
3. Get the adirass ol the tirst TCB in the reB table.

4. Il the:c are no TCBe le Lt ihen go to stop $]$.

5. :1 tris: ne 15 noc auing a triffic wist go to step 7 .

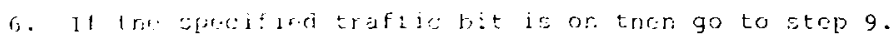

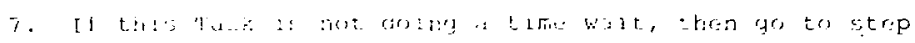
9.

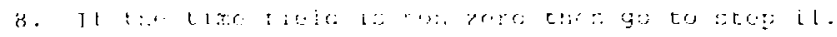

G. Srelect tar. liak.

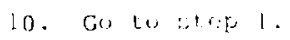

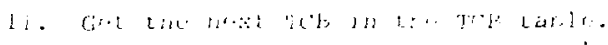

12 G

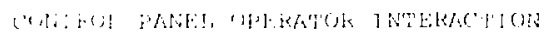

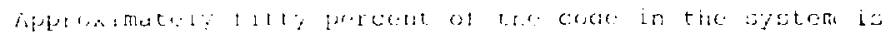

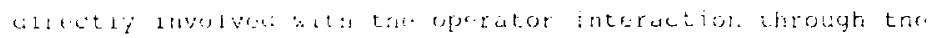

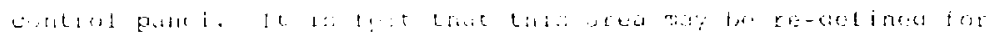

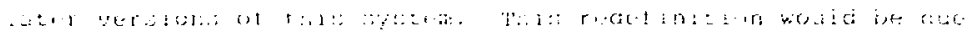

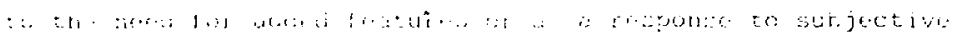

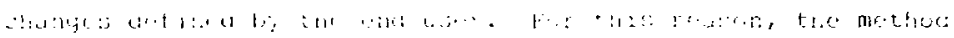

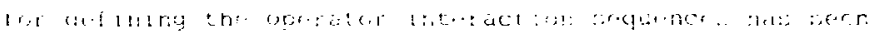

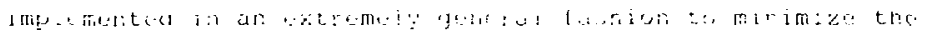

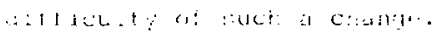

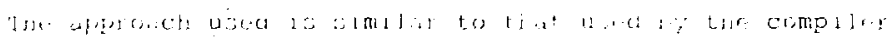

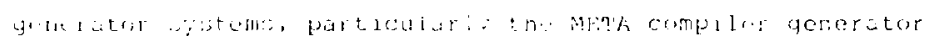

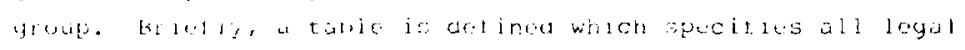

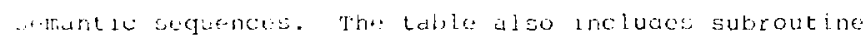

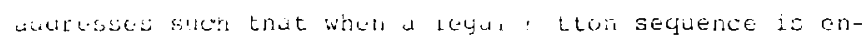

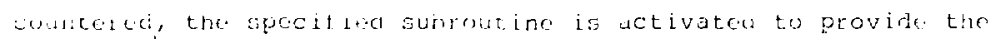
wervplate scmant le processing. Frror trap points are also

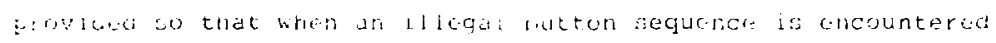

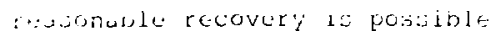


Tre number of legal suguences is infinite. For eximple,

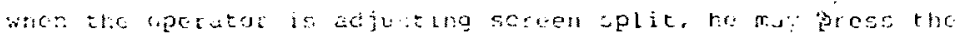

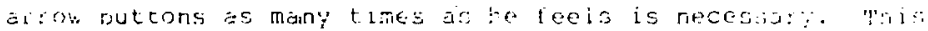

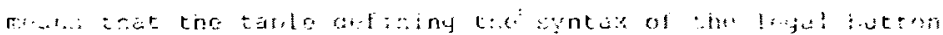

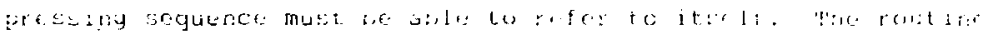

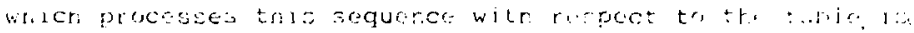

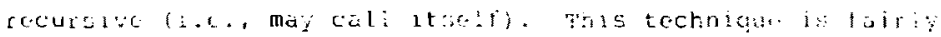
complex. The edvantage to using 1 t lo trat when a clange a:

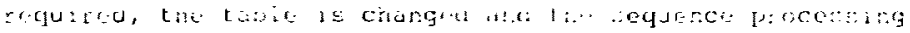

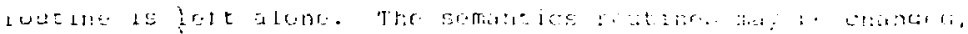

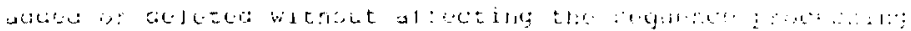
atertor.

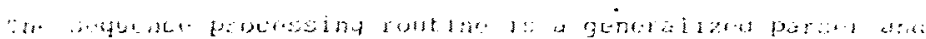

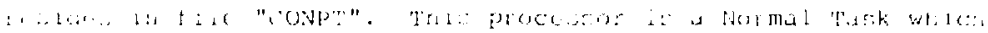

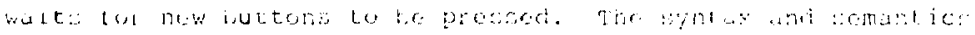

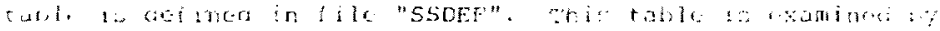
t: sogutuer procesedng rout ine in conjunction with the

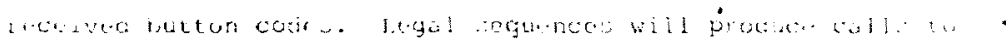

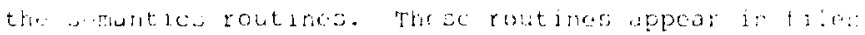
"s.yk!", "SEMk?", "SkMk?" and "SkMka".

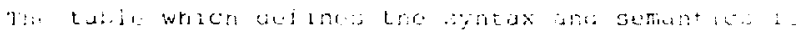

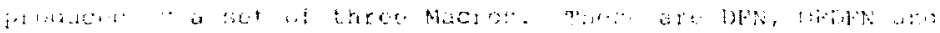

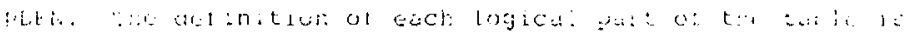

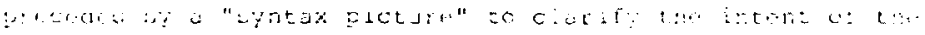

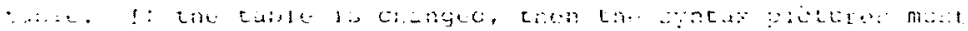

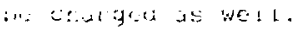

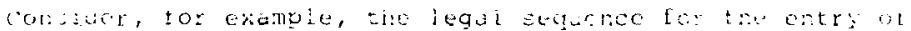

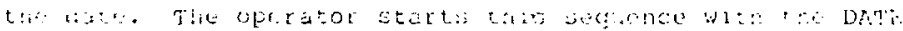

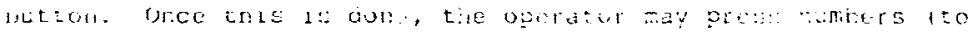

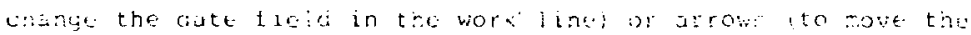

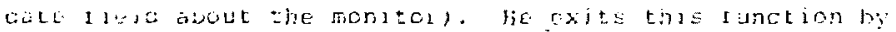


pressing ENTER (to copy the new date from the work line to the display fiela) or by pressing any new function button (TIME, SPLIT, MOTION, etc. to exit without the copy). The syntax protule tor tils is:

$[\hat{r} \mathrm{~L}]:$

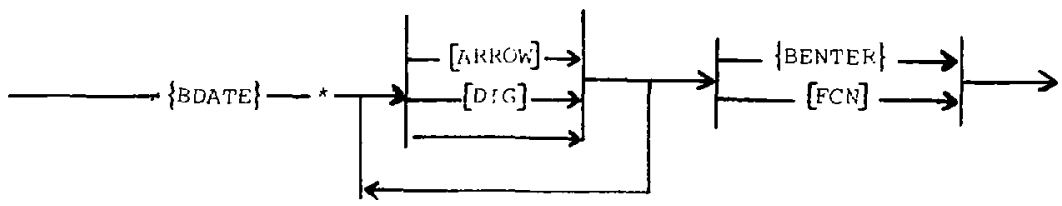

Numes in beaces. $\{f$, represent primitives (buttons). Nance un uruckets, [ ], tepresent ctiue conctructs. [FD] is the nume of this conetruct. [hRkOW] is urefined as any of the tour atrow ruttons, [org] is derinca as wny of the 10 digit bus -uns and [FCN] is oetrnea as any of the function huttons. Asterisks indicate error trup points.

A syntuct lcally legal sequence is any sequence which may be lound in a pach starting at the left of the syntar picture and lesving ot trie light. Nute the ability to have any number (liciuoing zero) of arrows or digits. An example iegal scusuce $1:$ :

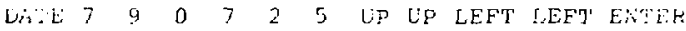

An uxumple ot an illegal sequerice would be:

$$
\text { DATE } 754 \text { LIP PAUSE }
$$

When an illegal primitive is encountered, the generalized parser will back up to the tilst error trap and waic for tro next jutton. This piovicies the error recovery feature. If no 
error trap is encountered during the backup, tne consticht returns ar error concition to the construct wnden reterenced the constuce in error. Wher a sementics routane ls called

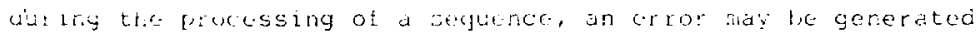

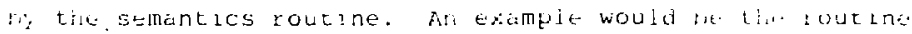
copy, which ls calleg when FNTER is presced, which returri: in error conoition if the date entereci was not valio. Error ruckle worne the sami for sumantlc crrors as it doos 10 : intitacto etrote.

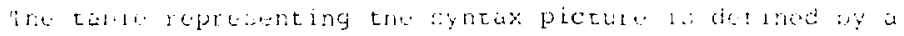

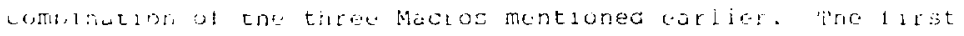

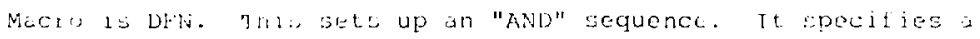

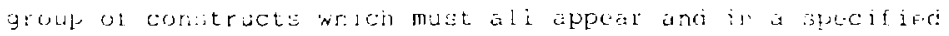
triche. In lne enowr cxample, the [FD] seguener is the

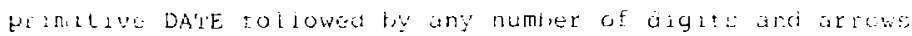

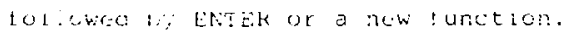

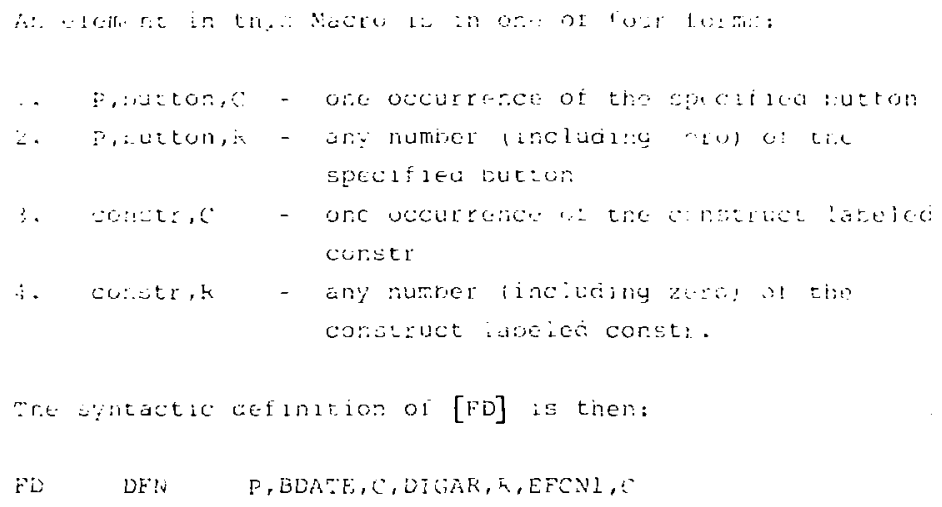




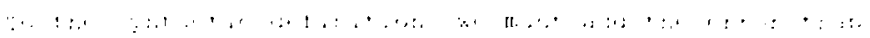

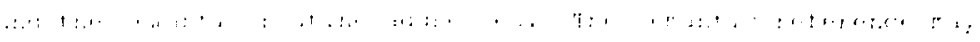

$$
\begin{aligned}
& \ldots, \ldots+1: 1: \text {... }
\end{aligned}
$$

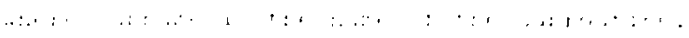

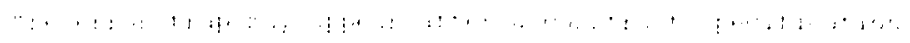

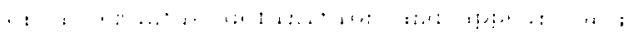

$$
\begin{aligned}
& ::: \vdots
\end{aligned}
$$

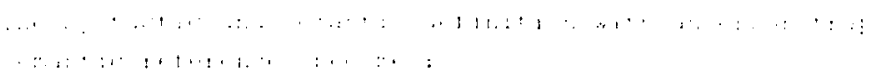

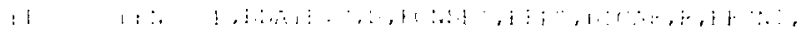

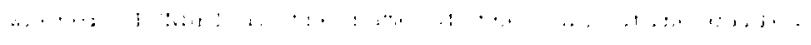

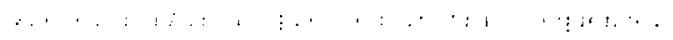

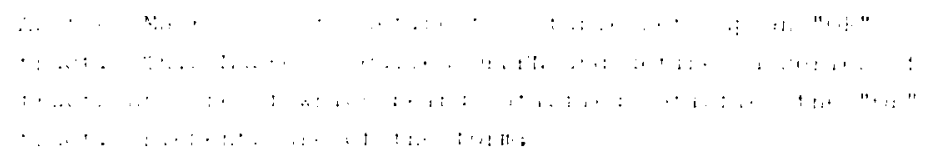

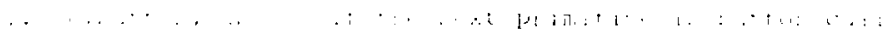

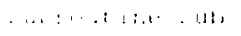

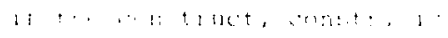

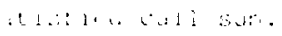

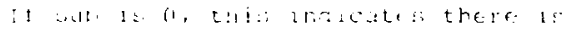

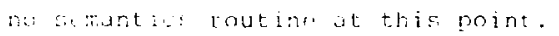

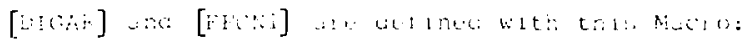




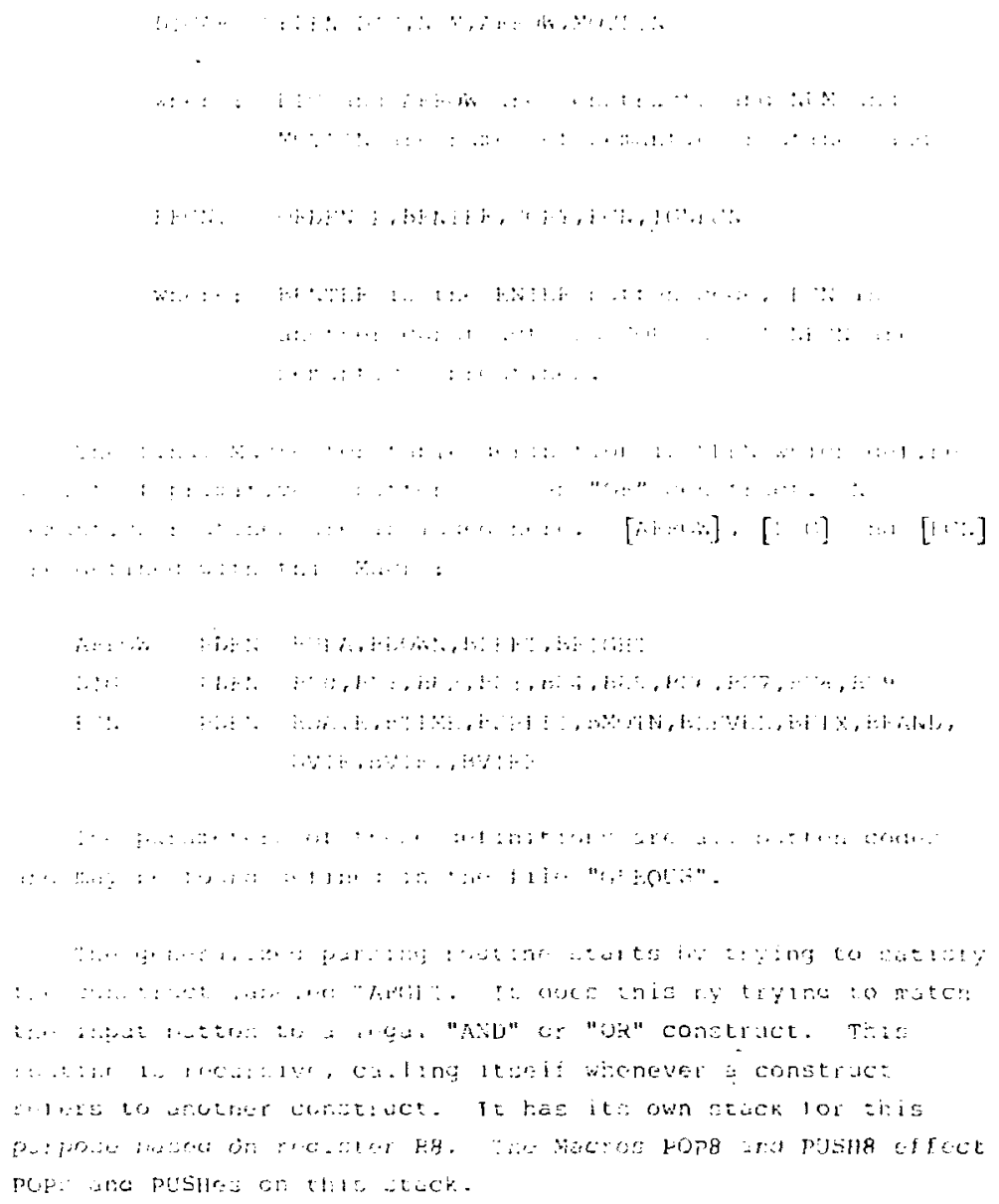




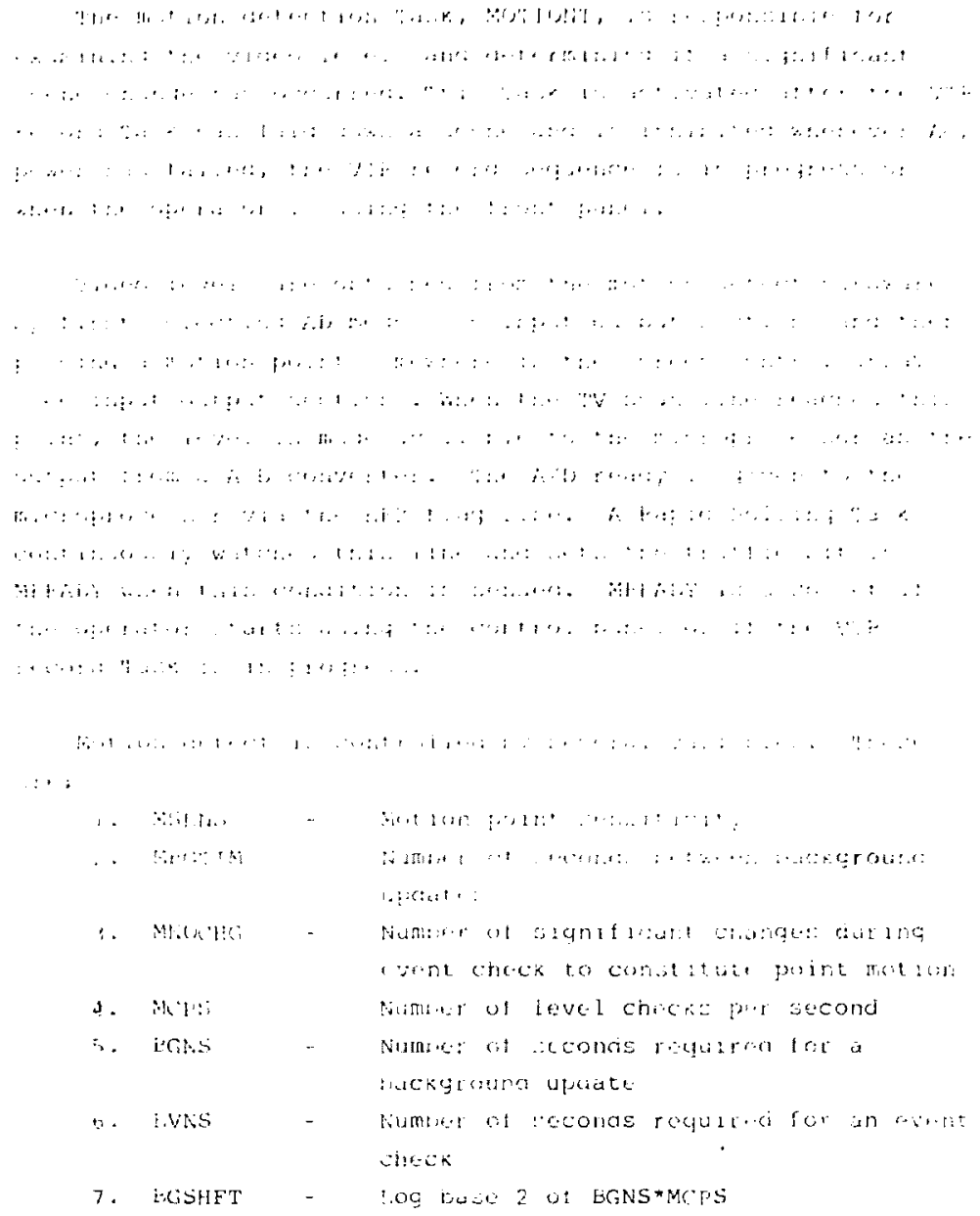




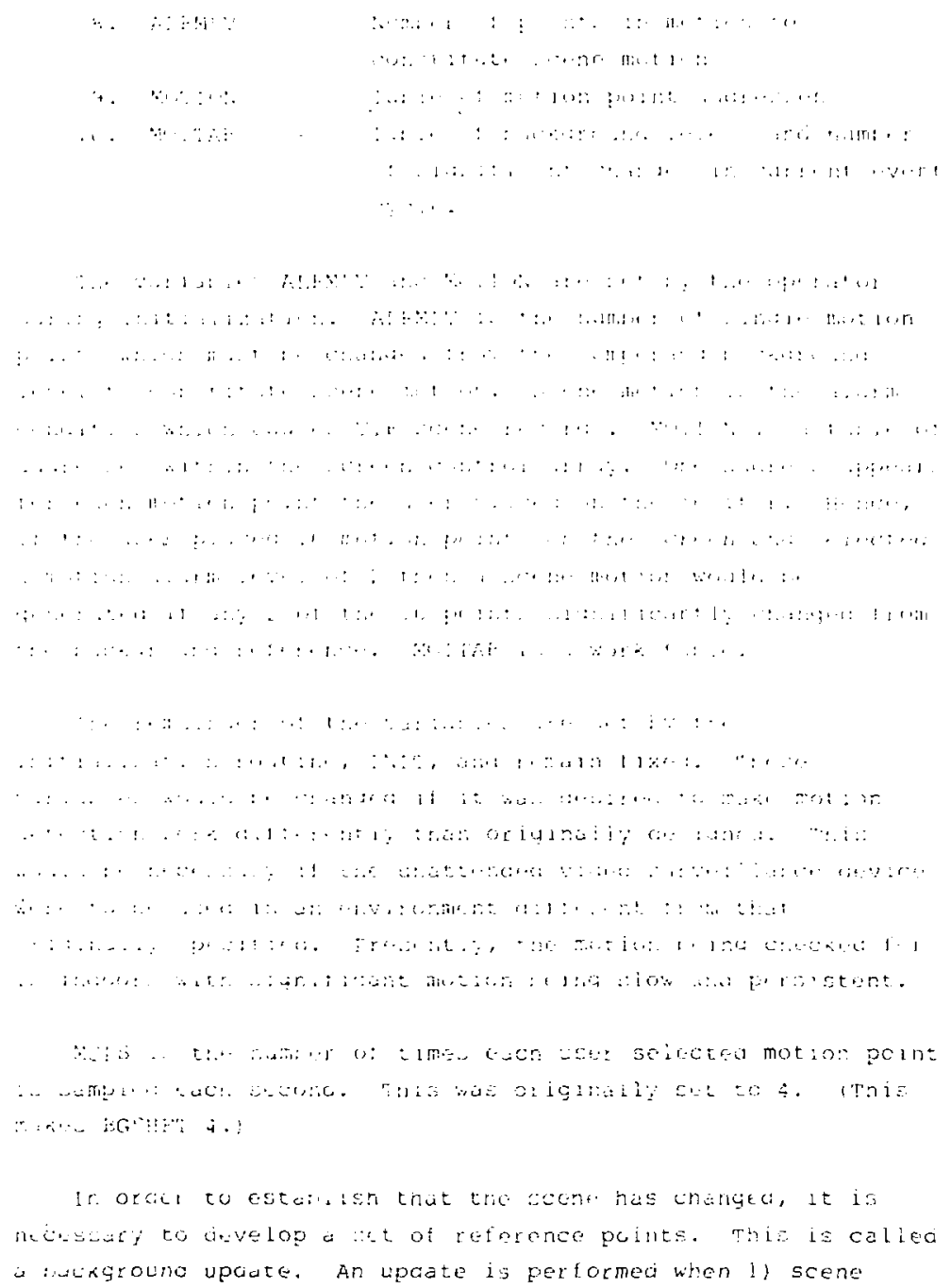




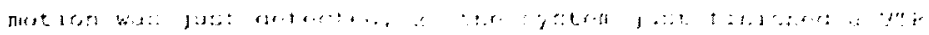

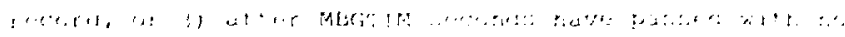

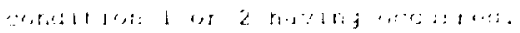

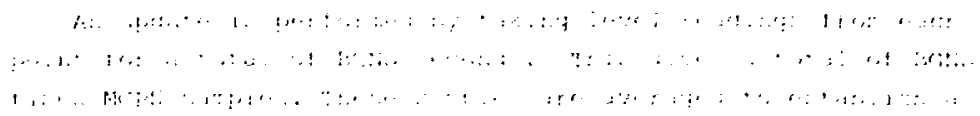

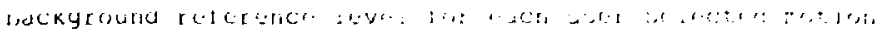

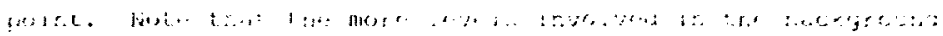

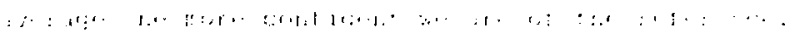

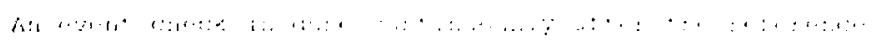

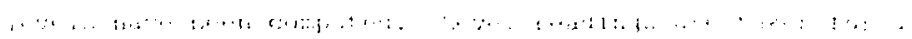

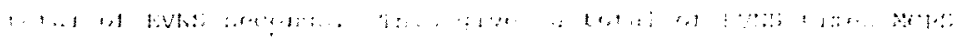

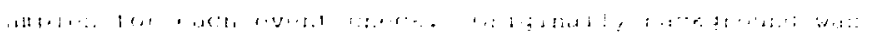

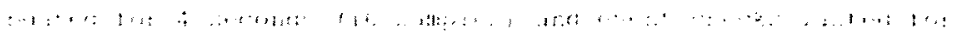

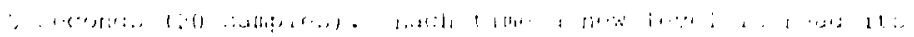

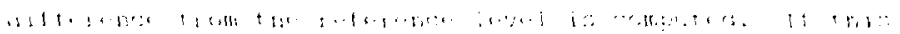

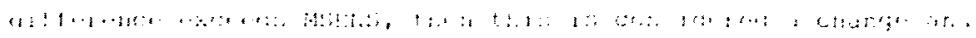

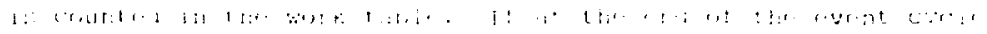

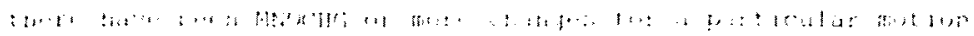

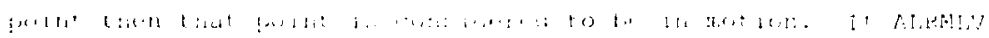

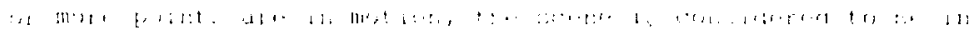

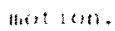

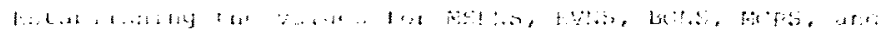

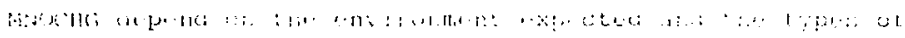

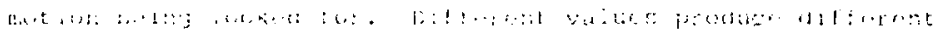

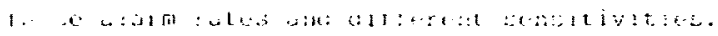

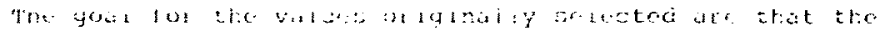

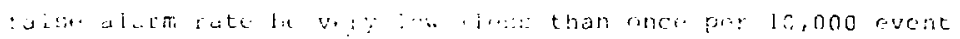

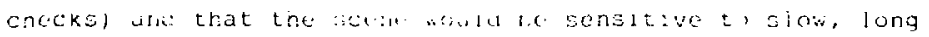

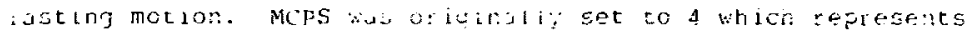

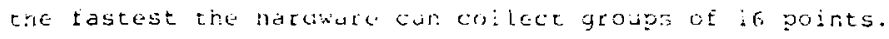




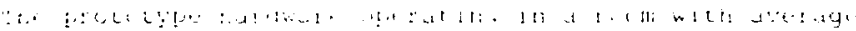

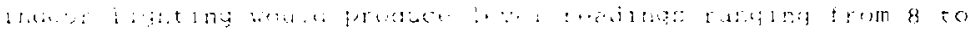

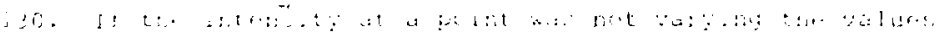

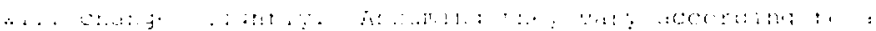

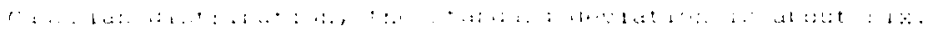

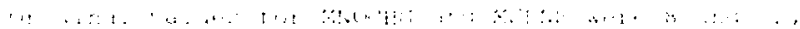

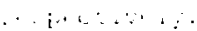

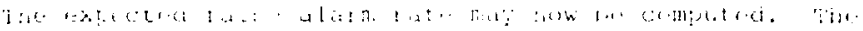

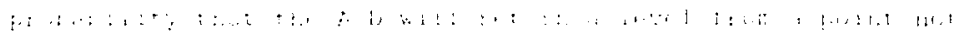

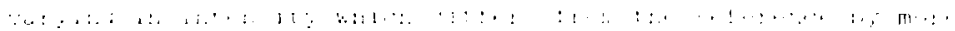

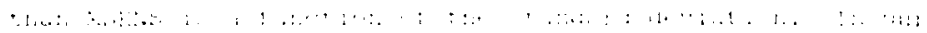

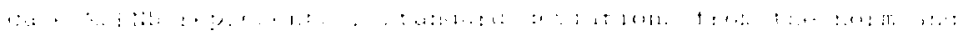

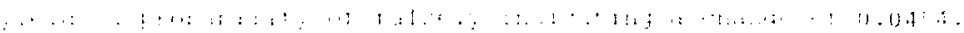

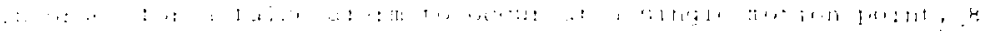

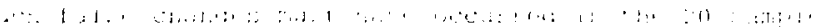

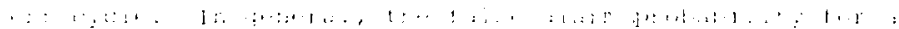

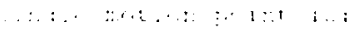

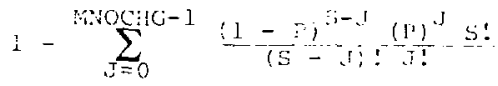

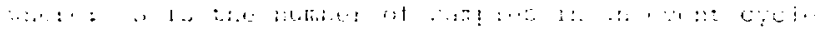

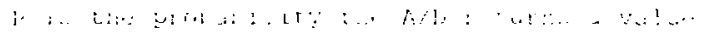

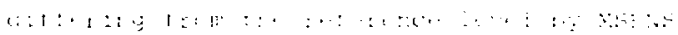

$$
\begin{aligned}
& \text { (1) } \quad \ldots 1, \ldots
\end{aligned}
$$

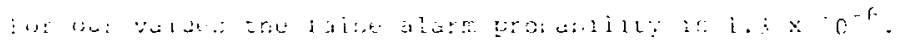

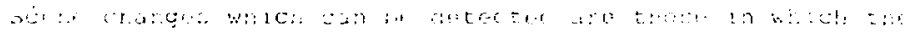

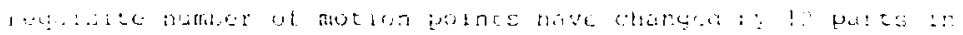

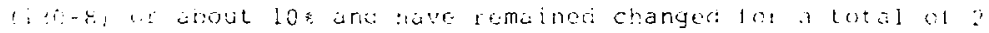

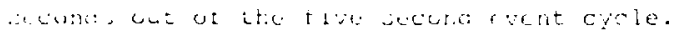




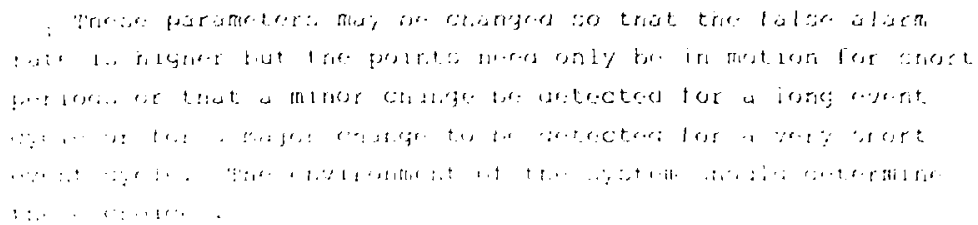




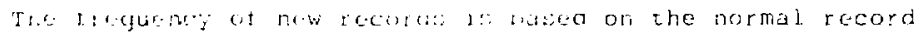

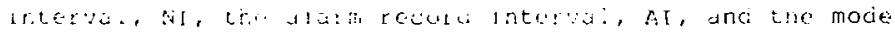

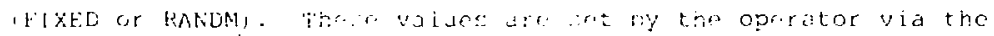

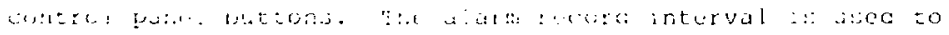

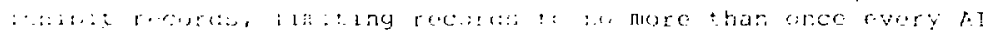

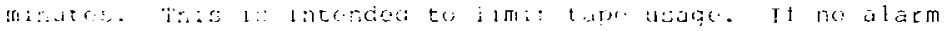

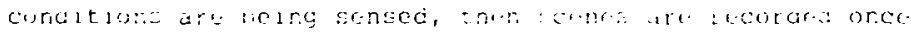

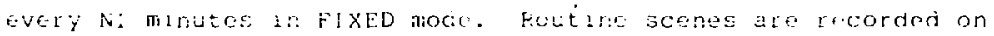

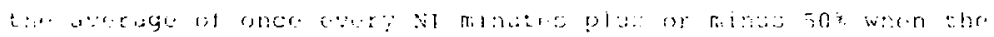

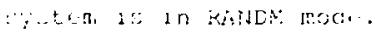

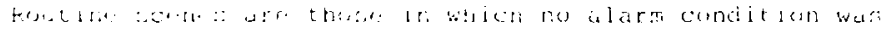

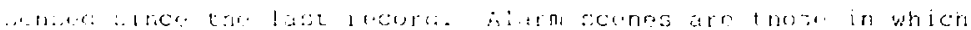

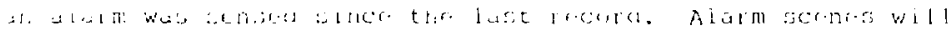

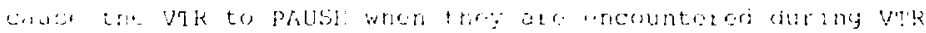

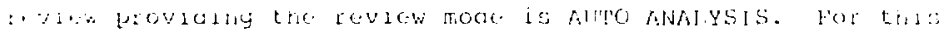

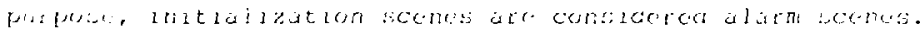

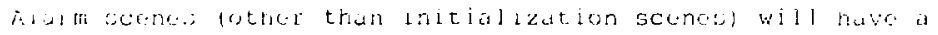

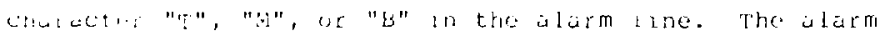

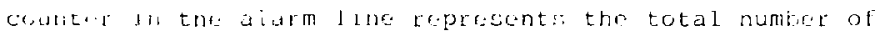

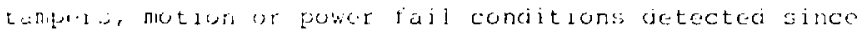

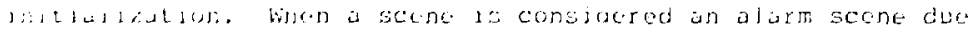

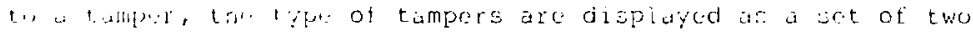

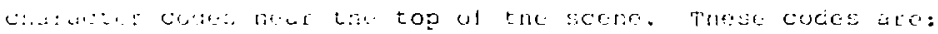

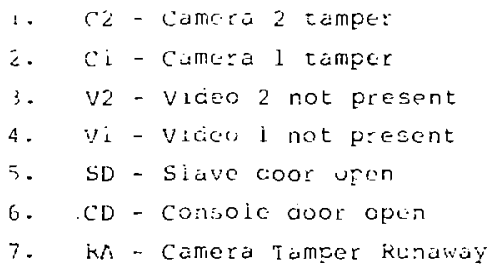




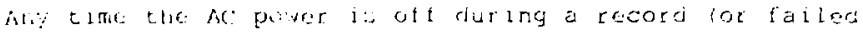

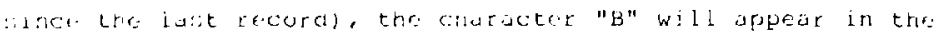
alarmi i ine.

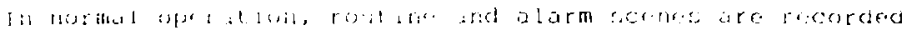

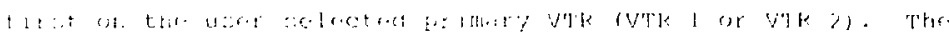

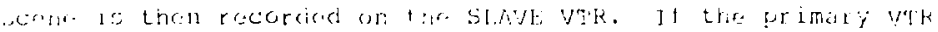

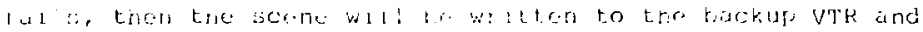

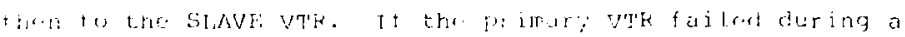

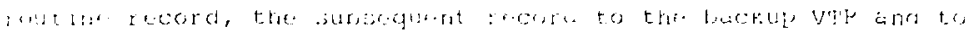

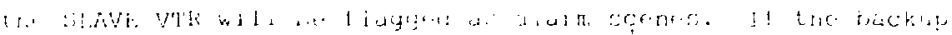

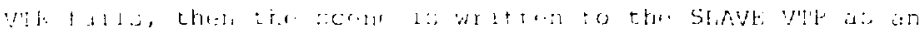

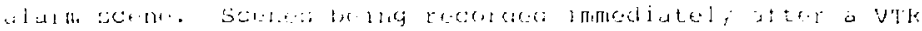

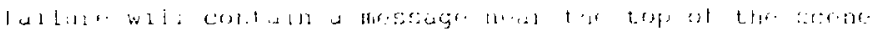

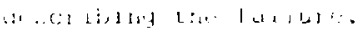

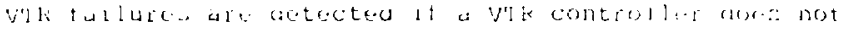

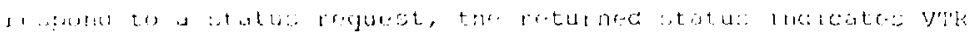

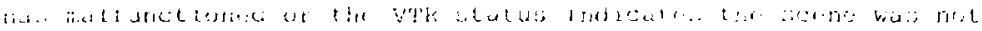

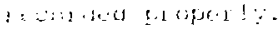

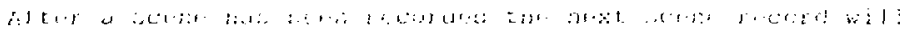

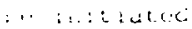

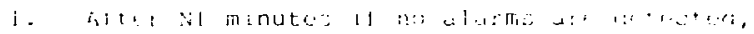

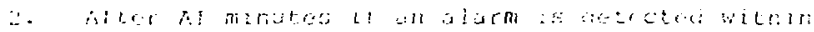

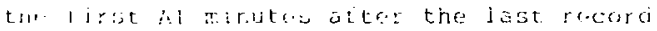

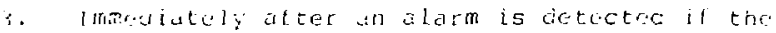
alarm is cotected altel At minutes rit tefore $\because$ III inates.

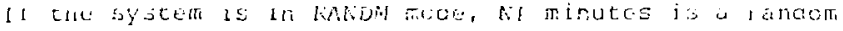

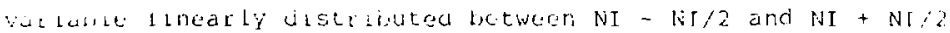
inliutus. 
It the $A C$ power fails, the camoras are turned utt which irribits motion cetect. Scenes wili be recolcied as described ar ave with the exception that scenes will not be recordea due

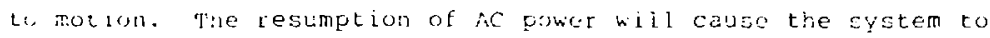
aret. to standara operatior.

wrenever the siave door il: openea, no lurther scenes are tecurded on the slaye until the system is re-initialized by the

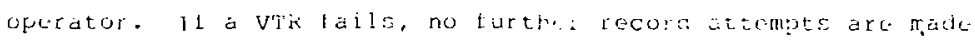
until the operator re-irit:alizets the system. Slave Vera

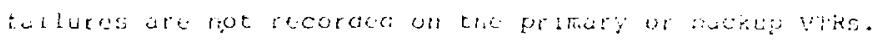


SUMMA:'

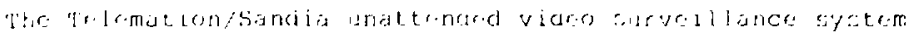

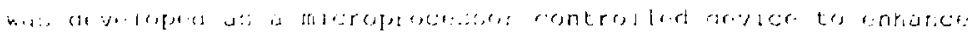

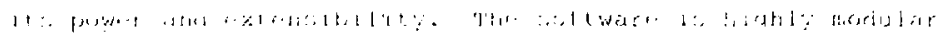

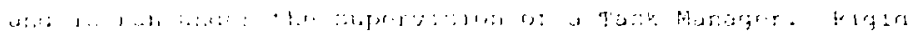

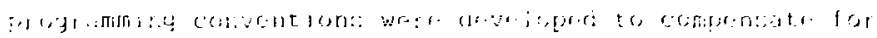

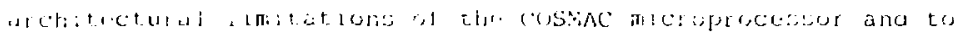

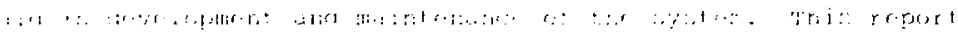

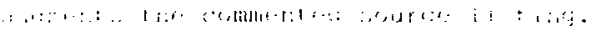

